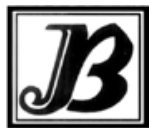

J. Bio-Sci. 23: 89-91, 2015

ISSN 1023-8654

http://www.banglajol.info/index.php/JBS/index

-Short communication

\title{
EFFECT OF SINGLE AND MULTIPLE AM FUNGAL INOCULANTS ON THE GROWTH PARAMETER OF OCIMUM BASILICUM VAR. THYSIFLORA BENTH
}

\author{
T Yeasmin $^{1}$, J Puttaradder ${ }^{*}$ and HC Lakshman ${ }^{3}$ \\ 1 Institute of Biological Sciences, University of Rajshahi, Bangladesh \\ 2,3Microbiology Laboratory, P.G. Department of Studies in Botany, Karnataka University, Karnataka, India
}

Most land plants form associations with mycorrhizal fungi. Mycorrhizas form mutualistic associations between fungi and plants roots. They are described as symbiotic, because the fungus receives photosynthetically derived carbon compounds and the plant has increased access to mineral nutrients and sometimes water. The symbiosis is characterized by branched fungal structures, arbuscules, which grow intercellularly without penetrating the host plasmalemma (Lakshman 2009). The main function of arbuscular mycorrhizal (AM) fungi is to enable Phosphorus for plants and increase uptake of $\mathrm{N}, \mathrm{K}, \mathrm{Zn}, \mathrm{S}, \mathrm{Fe}, \mathrm{Cu}, \mathrm{Mg}$, $\mathrm{Ca}$ and Mn. Extrametrical mycelium of AM fungi access phosphorus and translocate to cortical cells of plants. (Jone and Jakobsen 1995) and so increase the supply of slowly diffusing ions, such as phosphate to the plant (McArther and Knowles 1993).

Pure cultures of single species of AM fungus are being assessed for appreciable plant growth and crop production. AM fungi increased biomass production of sustainable agricultural crops. Multiple inoculations of the plants with AM fungi have often yielded increased biomass production. Therefore, the present investigation was carried out to understand the influence of single or multiple AM fungal inoculation on Ocimum basilicum Var. thysiflora Benth. Plants were raised in earthen pots measuring $(25 \times 30)$ with soil (sandy clay loam, $\mathrm{pH} 6.8$, organic matter $0.72 \%$, and indigenous spore population of Glomus spp.) was surface sterilized with $2 \%$ streptomycin. Before sowing the seeds, mixed inoculum (AM fungi colonized root bits plus chlamydospores) of different AM fungi was added to $4 \mathrm{~cm}$ below the soil of each experimental pots at the rate of $50 \mathrm{gm}$ soil inoculum/pot having $250-300$ spores. Following treatments with three replications were included in the study:

1. Soil without inoculum (Control)

2. Soil + Glomus bagyarajii VS Mehrotra ( $50 \mathrm{gm})$

3. Soil + Glomus macrocarpum Tulasne and C. tulasne (50 gm)

4. Soil + Rhizophagus fasciculatus (Thaxt.) C. Walker and A. Schüßler (50 gm)

5. Soil + Glomus bagyarajii $(25 \mathrm{gm})+$ G. macrocarpum $(25 \mathrm{gm})$

6. Soil + Glomus bagyarajii $(25 \mathrm{gm})+R$. fasciculatus $(25 \mathrm{gm})$

7. Soil + Glomus macrocarpum (25 gm) $+R$. fasciculatus ( $25 \mathrm{gm})$

8. Soil + Glomus bagyarajii (16.66 gm) + G. macrocarpum (16.66 gm) + R. fasciculatus (16.66 gm)

Pots of all the treatments were maintained under greenhouse conditions. Plants were watered on alternate days. $15 \mathrm{ml}$ of minus $\mathrm{P}$ Hoagland nutrient solution was given once in 15 days for experimental pots. Plants

*Author for correspondence: j.puttaradder@gmail.com 
were uprooted periodically and per cent colonization of mycorrhizal roots was recorded by methods of Phillips and Hayman (1970). At the same time the spores were extracted from the root washings by the method of the wet sieving decanting technique of Gerdemann and Nicolson (1963) and spore count of rhizosphere soil was recorded. Shoot dry biomass was recorded in terms of dry weight of shoot and root/plant at the harvest. Phosphorus content in the shoot was determined calorimetrically by the phosphoric yellow colour method outlined by Jackson (1973).

The AM fungal inoculants were evaluated for Ocimum basilicum Var. thysiflora Benth individually as well as in different combinations caused an improvement not only in mycorrhizal colonization in root, spore count in rhizosphere soil, and shoot biomass, yield, and phosphoric content in shoots. However, as expected the magnitude of improvement varied with the AM inoculants and their combinations. While maximum improvement in spore count was caused by an inoculum of G. macrocarpum. On the other hand combined inoculum of all the three AM fungi was most effective in improving mycorrhizal colonization, shoot and root biomass, and $\mathrm{P}$ content in shoots (Table 1). It was also very effective in improving the yield. The results of the present investigation are in conformity with the results reported earlier by (Sivaprasad et al. 1990, Yao 1996, Atti et al. 2010, Lakshman and Kurandwad 2014). By giving importance to plant biomass and phosphorus content, but not neglecting the other characteristics, Glomus macrocarpum was found to be the most promising fungus for inoculating Ocimum basilicum Var. thysiflora Benth in nursery. The next best fungus was Rhizophagus fasciculatus. Daft and Nicolson (1972) reported earlier that higher root colonization allows more fungal host contact and more exchange of nutrients, hence better plant growth. In conclusion repeated observations of this kind with other plants will confirm the superiority of multiple inocula and open a new avenue to achieve better productivity.

Table 1. The effect of G. bagyarajii VS Mehrotra, G. macrocarpum Tul and Tul, R. fasciculatus (Thaxt.) C. Walker and $A$. Schüßler, on growth characteristics of $O$. basilicum Var. thysiflora Benth after 90 days of sowing.

\begin{tabular}{lccccc}
\hline Treatments & SDW & RDW & PMC & SN & P content in shoot \\
\hline Control & $1.5 \pm 0.2 \mathrm{f}$ & $0.20 \pm 0.01 \mathrm{~d}$ & $33 \pm 1.01 \mathrm{e}$ & $68 \pm 0.30 \mathrm{f}$ & $0.04 \pm 0.02 \mathrm{f}$ \\
Glomus bagyarajii (GB) & $1.6 \pm 0.9 \mathrm{e}$ & $0.25 \pm 0.01 \mathrm{~d}$ & $76 \pm 0.10 \mathrm{a}$ & $129 \pm 0.05 \mathrm{~b}$ & $0.08 \pm 0.00 \mathrm{c}$ \\
Glomus macrocarpum (GM) & $2.1 \pm 0.0 \mathrm{~d}$ & $0.45 \pm 0.0 \mathrm{c}$ & $85 \pm 0.00 \mathrm{~b}$ & $158 \pm 0.02 \mathrm{a}$ & $0.10 \pm 0.01 \mathrm{~b}$ \\
Rhizophagus fasciculatus (RF) & $1.8 \pm 0.0 \mathrm{e}$ & $0.33 \pm 0.01 \mathrm{~d}$ & $80 \pm 0.05 \mathrm{a}$ & $116 \pm 0.10 \mathrm{c}$ & $0.08 \pm 0.00 \mathrm{c}$ \\
GB + GM & $3.9 \pm 0.0 \mathrm{c}$ & $0.71 \pm 0.0 \mathrm{~b}$ & $71 \pm 0.10 \mathrm{c}$ & $113 \pm 0.03 \mathrm{~d}$ & $0.13 \pm 0.00 \mathrm{a}$ \\
GB + RF & $3.7 \pm 0.0 \mathrm{~d}$ & $0.52 \pm 0.02$ & $76 \pm 0.20 \mathrm{~b}$ & $109 \pm 0.04 \mathrm{~d}$ & $0.12 \pm 0.00 \mathrm{c}$ \\
GM + RF & $5.7 \pm 0.0 \mathrm{~b}$ & $0.68 \pm 0.0 \mathrm{~b}$ & $67 \pm 0.01 \mathrm{~d}$ & $102 \pm 0.06 \mathrm{e}$ & $0.11 \pm 0.00 \mathrm{~d}$ \\
GB + GM + RF & $9.7 \pm 0.0 \mathrm{a}$ & $0.93 \pm 0.0 \mathrm{a}$ & $90 \pm 0.00 \mathrm{a}$ & $100 \pm 0.00 \mathrm{e}$ & $0.20 \pm 0.00 \mathrm{a}$ \\
\hline
\end{tabular}

Data represents means \pm SE of 3 replicates; each experiment was repeated thrice. Mean separation within column by Duncan's multiple range test (DMRT) at $\mathrm{P}<0$.

SDW-Shoot Dry Weight, RDW-Root Dry Weight, PMC- Percent Mycorrhizal Colonization, SN- Spore Number, RF- Rhizophagus fasciculatus, GM- Glomus macrocarpum, GB- Glomus bagyarajii. 


\section{References}

Atti T, Danny C, Fabien H, Louis L, Andres W and Fritz O (2010). Efficacy ofindigenous arbuscular mycorrhizal fungi for promoting white yam (Dioscorea rotundata) growth in West Africa. Applied Soil Ecology 45: 92-100.

Daft MJ and Nicolson TH (1972). Effect of endogone mycorrhiza on plant growth IV. Quantitative relationship between the growth of the host and the development of the endophyte in tomato and maize, New Phytologist 71: 287-295.

Gerdemann JW and Nicolson TH (1963). Spores of mycorrhizal endogone species extracted from the soil by wet sieving and decanting. Transactions of the British Mycological Society 46: 235-244.

Jackson (1973). Soil chemical analysis. Prantice Hall of India. Pvt. Ltd. New Delhi, 284 pp.

Jone E and Jakobsen I (1995). Growth and extracellular phosphatase activity of arbuscular Mycorrhizal hyphae as influenced by soil organic matter. Soil organic matter. Soil Biology and Biochemistry 27: 1153-1159.

Lakshman HC (2009). Interaction between AM fungi and Rhizobium and their effect on Cassia occidentalis. National Journal of Plant Science 15(1): 25-30.

Lakshman HC and Kurandawad JM (2014). Selection of suitable AM fungi for Capsicum annum L. Bulletin of Basic and Applied Biology 3(2): 89-95.

McArther DAJ and Knowles NR (1993). Influence of VAM and phosphorus nutrition on growth, development and mineral nutrition of potato. Plant Physiology 102: 771-782.

Phillips M and Hayman DS (1970). Improved procedure for clearing roots and staining, parasitic and VAM fungi for rapid assessment of infection, Transactions of the British Mycological Society 55: 158-160.

Sunder SK, Palavesam A and Parthipan B (2011). AM fungal diversity in selected medicinal plants of Kanyakumari district, Tamil Nadu, India. Indian Journal of Microbiology 54(3): 259-265.

Sivaprasad P, Sulochana KK and Nair SK (1990). Comparative efficiency of different VAM fungi on cassava (Manihot esculenta). Journal of Root Crops 16(1): 39-40.

Yao KM (1996). Influence de difference especes de champignons endomycorrhiziens sur la croissance et le rendement de cultivars d'oignon (Allium cepa L.) soumis a differentes conditions culturales. Memoire de maitrise No. 15508, Universite de Laval, Quebec, Canada. 
Yeasmin et al. 